\title{
FOOD SHOPPING BEHAVIOR: A LONG WAY TO PREVENT FOOD WASTE
}

\author{
Mahestu N Krisjanti \\ Universitas Atma Jaya Yogyakarta \\ Email : mahestu.krisjanti@uajy.ac.id \\ Agnes Gracia Quita \\ Universitas Atma Jaya Yogyakarta \\ Email : agnesgraciaquita@gmail.com
}

Received: October 2019; Accepted: December 2019; Available online: January 2020

\begin{abstract}
Food sustainability is becoming big concern these last couple years, due to the food scarcity issues in many countries. However in contrary previous studies reported the food waste behavior is getting bigger at this moment because of over food preparation, food stocking, undesired food, and food packaging. Over all, most of these issues come from the food shopping behavior. People tend to buy more food products than what they need. Therefore, the determinant of food shopping behavior is urgently found in order to find the solution to drive people to have planned food buying behavior. This research elaborates how motivation to prevent food waste would affect food shopping behavior. The data collection through survey has been done in the young adult community. The finding indicates that having motivation to prevent food waste will contribute to well-planned food shopping behavior. Furthermore, the research also indicates that female shows higher motivation in preventing food waste as also reported in some previous studies that report similar result.
\end{abstract}

Keywords: food waste, food waste prevention, food shopping behavior.

\begin{abstract}
Abstrak
Keberlanjutan ketersediaan pangan menjadi perhatian besar beberapa tahun terakhir ini, terutama karena munculnya masalah kelangkaan pangan di banyak negara. Namun demikian, beberapa penlitian terdahulu melaporkan peningkatan perilaku membuang makanan terutama karena adanya kecenderungan menyiapkan makanan yang berlebihan, pola penyimpanan makanan, dan pembelian makan yang terlalu banyak. Beberapa pola perilaku membuang makanan adalah efek dari strategi pemasaran yang di lakukan oleh banyak perusahaan, dan mendorong konsumen untuk membeli lebih banyak produk makanan daripada yang mereka butuhkan. Oleh karena itu, menjadi suatu yang penting untuk menemukan determinan perilaku belanja makanan, terutama untuk mendorong munculnya perencanaan perilaku pembelian makanan. Penelitian ini menguraikan bagaimana motivasi untuk mencegah limbah makanan akan mempengaruhi perilaku belanja makanan. Pengumpulan data melalui survei telah dilakukan di komunitas dewasa muda. Temuan menunjukkan bahwa memiliki motivasi untuk mencegah limbah makanan akan berkontribusi pada perilaku belanja makanan yang terencana dengan baik. Selain itu, penelitian ini juga menunjukkan bahwa perempuan menunjukkan motivasi yang lebih tinggi dalam mencegah limbah makanan seperti juga dilaporkan dalam beberapa penelitian sebelumnya yang melaporkan hasil yang sama.
\end{abstract}

Kata Kunci: membuang makanan, pencegahan membuang makanan, perilaku belanja makanan.

How to Cite: Krisjanti, M. N., \& Quita, A. G. (2020). Food Shopping Behavior: A Long Way to Prevent Food Waste. Media Ekonomi dan Manajemen, 35(1), 92-99. doi: doi: http://dx.doi.org/10.24856/mem.v35i1.1251. 


\section{INTRODUCTION}

Food waste is perceived as the nonuse food in the stages of distribution and consumption (Gustavsson, Cederberg, Sonesson, Van Otterdijk \& Meybeck, 2011). Furthermore, Leal Filho and Kovaleva (2015) reported that it may emerge as a result of inappropriate behavior of producers, retailers or consumers, and also the lack of technological inputs. These last couple years, food waste is becoming a critical problem globally. Indeed, there is significant part of the food produced is thrown out over, approximately 1.3 billion tons of food are wasted to nothing per year (Gustavsson, 2011). However even though this issue became a concern to many governments all over the world, the food waste problem is yet to be solved (Bräutigam, Jörissen \& Priefer, 2014). Food waste is expensive, it affects our environment negatively, it has certain social consequences, and a considerable amount of food waste comes from our household. There are so many serious consequences of household food waste (Graham-Rowe, Jessop \& Sparks, 2014). That is why it is still very important to solve this problem by building a complete understanding, especially from the consumer or individual perspective.

Previous study reported that one of food waste the antecedents in the house hold is buying too many food (Porpino, Parente, and Wansink, 2015). Therefore, understanding how food shopping behavior is developed may lead to solve the main problem. Food waste could be prevented by efficient food shopping behavior. This is shown from the condition if the consumer does not buy more food than the amount of their needs, then the possibility to discard leftovers or excess food supplies will be reduced. Therefore examining the understanding of food shopping behavior is needed to be able to develop good communication strategies in reducing food waste campaigns. The previous studies mostly concerned on the contribution of shopping behavior on food wasting. However, no study has done on how shopping behavior was built regarding the food waste prevention. This study is inquiring the contribution of the motivation to reduce the food waste to the food shopping behavior. Furthermore, evaluating the role of gender in in food buying behavior is also conducted.

\section{LITERATURE REVIEW Food Waste and Shopping Behavior}

There are at least four antecedents of food waste in the household (Porpino et al, 2015). First, during buying process, such as excessive food purchase. Second, during food preparation, such as over-preparation and aesthetics. Third, during consumption, such as leftover food. Fourth, food storage, such as inappropriate food techniques. Furthermore, finding the solution of food waste behavior requires a knowledge of the determinant. This study emphasizes on one of the antecedents, which is shopping behavior. Some previous studies indicate the contribution of shopping behavior in food-wasting behavior. Baumeister (2002) report that consumers are encouraged to do excessive food buying due to the exposure to marketing strategy, that will influence the consumers to buy impulsively. Moreover, commercially processed food will stimulate consumers to stock pile food or buy in bulk.

As it is explained in the theory of planned behavior, that attitude will influence behavior decisions, then the same concept will be explored to this model. Theory of Planned Behavior has been widely used as a theoretical lens to explain consumer behavior in food waste context. For example, Ghani et al (2013) explained food waste separation behavior at home using the TPB and an additional construct of situational factors (Aktas, Sahin, Topaloglu, Oledinma, Huda, Irani \& Kamrava, 2018). The theory of planned behavior posits that intentions can be 
predicted by attitudes. In this study attitudes are examined with motivation as a general attitude measurement typically used in a TPB context. In this context, authors want to examine how motivation to reduce the food waste will contribute to food shopping behavior. While a share of food waste avoidance actions might be chosen in order to save money through "good housekeeping", enacting the whole range of actions is rather due to ethical reasons related to fairness (e.g., in light of worldwide hunger), values or religious beliefs or environmental concerns (Aschemann-Witzel, De Hooge, Amani, Bech-Larsen \& Oostindjer, 2015). Due to the lack of previous studies on the motivation to reduce to food waste and its contribution in developing the food shopping behavior, therefore the hypothesis of this study was built on the study of TPB in predicting food waste behavior. This is the hypothesis of the study:

H1: Motivation to reduce the food waste would contribute to shopping behavior.

It is also important to include demographic characteristics which may act as proxies for unspecified preferences and also to compare to other studies that have used demographic characteristics (Zepeda \& Li, 2006). Koivupuro, Hartikainen, Silvennoinen, Katajajuuri, Heikintalo, Reinikainen and Jalkanen (2012) stated that gender could play a considerable role when studying the causes of food waste.

In a study on food waste and gender, Cohen et al (2013) reported that there is no difference in food waste by gender. However, according to (Silvennoinen, Katajajuuri \& Hartikainen, 2014) there is correlation between the waste amounts and the gender responsible for food purchases. Furthermore, the food waste would be higher in those households where a woman has responsibility to do shopping than in households where a man has involvement in shopping. Moreover, Kuo and Shih (2016) found that female waste more food that male do. Based on these previous studies, this research develop the hypothesis, which is:

$\mathrm{H} 2$ : Based on gender, female and male would have different motivation to reduce the food waste.

\section{RESEARCH METHODS}

This research is an exploratory study to test the contribution of motivation to reduce food waste behavior through shopping behavior. The respondents of this study are the adults have responsibility to purchase food for personal consumption or family. There are 153 respondent that contribute in the study. The questionnaire consists of 15 close-ended items (Table 1) which represents 2 variables was used to collect the primary data. Motivation to reduce food waste is the first variable, which is comprising 7 items which were modified from Neff et al (2015). This variable was developed to measure the reasons why the respondents discard their foods. The second variable is Shopping Behavior, which is adapted from the same study, consists of 8 items to measure the behavior of consumers especially before and during they are going for shopping. After all items in questionnaire were validated and also passed the minimum requirement of the reliability test, the data went to the next step, which is regression. Furthermore, to examine if male and female would have different motivation to reduce food waste, the independent sample t-test would be run.

\section{RESULT AND DISCUSSION Result}

The descriptive analysis on each items of motivation to reduce food waste has been done to describe which motivation would be dominate. Table 2 provides the description of the motivation to reduce food waste. The respondents give the highest score on the item of "thinking about hungry people", followed by the 
item of "guilt about waste in general". The items with lowest score are "saving money" and "concern about the issues of energy and water".

The result of the regression analysis (Table 3) indicates that motivation to reduce food waste contributes to the shopping behavior. The result reports adjusted $\mathrm{R}^{2} 19 \%$ that means $19 \%$ of shopping behavior can be explained by the motivation to reduce the food waste, while the remaining $81 \%$ would be explained by other than the motivation to reduce the food waste. The regression analysis also indicates that motivation to reduce food waste shows positive beta coefficient
(0.442), meaning that the motivation to reduce the food waste has positive effect to shopping behavior. The higher the motivation to reduce food waste, the better the respondents' behavior in shopping. Furthermore, they will be more careful in buying food products such as checking the fridge before shopping and buying not too many food that the need.

The result of the independent sample t-test (Table 4) indicates that male and female show different motivation to reduce food waste. Females have higher motivation in reducing the food waste compared to males do.

Table 1. The Measurement of Motivation to Reduce Food waste and Shopping Behavior

\begin{tabular}{ll}
\hline \multicolumn{1}{c}{ Motivation to Reduce Food Waste } & \multicolumn{1}{c}{ Shopping Behavior } \\
\hline Saving money & $\begin{array}{l}\text { Check the fridge and cupboard before } \\
\text { shopping }\end{array}$ \\
Setting example for others & $\begin{array}{l}\text { Estimate quantities needed before shopping } \\
\text { Managing household efficiently }\end{array}$ \\
Make a shopping list \\
Guilt about waste in general & Stick to shopping list in the store \\
Making a difference through my actions & Plan meals before shopping \\
Concern on the issues of energy and water & Buy too much food due to sales \\
& Buy too much food due to packaging \\
& Buy too much food due to tempting products \\
\hline
\end{tabular}

Table 2. The Mean of Motivation to Reduce Food Waste

\begin{tabular}{lc}
\hline \multicolumn{1}{c}{ Motivation to Reduce Food Waste } & Mean \\
\hline Saving money & 3.83 \\
Setting example for others & 4.05 \\
Managing household efficiently & 4.04 \\
Thinking about hungry people & 4.27 \\
Guilt about waste in general & 4.25 \\
Making a difference through my actions & 4.12 \\
Concern on the issues of energy and water & 3.82 \\
\hline
\end{tabular}

Table 3. The Result of Regression Analysis

\begin{tabular}{llrc}
\hline & Beta Coefficient & $\mathrm{t}$ & \multicolumn{1}{c}{ Sig. } \\
\hline Motivation & .442 & 6.053 & .000 \\
Adj R & .19 & & \\
F & .000 & & \\
\hline
\end{tabular}

Table 4. The Result of Independent Sample t-Test

\begin{tabular}{llllr}
\hline & Gender & Mean & t & \multicolumn{2}{r}{ Sig. (2-tailed) } \\
\hline Motivation & Female & 4.1463 & 2.736 & .007 \\
& Male & 3.9441 & & \\
\hline
\end{tabular}




\section{Discussion}

The finding of the previous study indicates that consumers' food waste is driven mainly their motivation not to waste food. From consumers' point of view, consumers have rather negative attitudes towards food waste; they felt bad about wasting food (Evans, 2012) and were concerned when they threw food away (Abeliotis et al., 2014). Besides general attitudes towards food waste, three other types of attitudes can be identified from previous studies on consumers' perceptions of food waste: environmental, financial and health concerns. Financial concerns due to over purchasing were often mentioned as a factor that motivated people to reduce their food waste (Graham-Rowe et al., 2014).

Among reported motivations for reducing food discards, thinking about hungry people topped the list, guilt about waste in general second, followed by making a difference through my actions. These findings does not support other studies (Quested, 2013; Wrap, 2007; Parizeau, 2015; Stevan et al., 2013). To be concluded, there is two financial factors that motivate to prevent food waste. The first reason is to save money.

Regarding the financial factor, the finding of this study does not support the previous by Neff et al (2015) that position saving money as the most important motivation. For more focus, according to this research context, you adults have very limited incomes or financial resource, therefore it is very reasonable for them to organize food purchases to have leftover allowances to save, so that they feel financially secure. The second reason is to manage their expenses more efficiently. Young adults have a lot of needs to support their learning process, while with pocket money that they have is impossible just to spend it for food only, even though food is a primary need. Therefore you adults will try to manage their money to be sufficient for various needs. While, in this study, the item of saving money was scored low by respondents.

But in fact the motivation to reduce the behavior of disposing of food is not only due to limited financial conditions, but also based on social care and also an understanding of the environment. To summarize, household food waste prevention is highly relevant not only for personal, but especially for an ecological point of view (Klöckner, 2015). Reducing food waste is environmentally important as it keeps food out of landfills. Food is waste itself along with these chain, that the greater food waste is, the bigger environmental impact, and students concern about this issues. Along with the consideration to energy and natural resources like water that expended in processing, transporting, storing and cooking it.

Young adults are also motivated to disrupt food shopping behavior because they are motivated by high social awareness in the context of reducing food waste. High social care and consideration to some issues such as poverty, hunger, become some of the reason why students manage food shopping behavior. In the other hand student also intended to make changes to the society by showing positive examples. Managing the patterns of food consumption is also motivated by their guilt feeling of wasting food. It might be influenced by social norms and values that already taught to them since childhood.

From business perspective, in general reducing food loss and waste has financial benefits not only for individual and household but also businesses as well. It makes economic sense at the small scale, by lowering household food bills and even at the large scale it will reduce disposal costs for restaurants, processors and farmers. According to WRAP, grocery retail food waste costs $£ 3,100$ per tonne, manufacturing waste costs $£ 1,200$ per tonne, and packaging waste costs $£ 1,600$ per tonne. By targeting these areas and investing in more sustainable solutions, 
costs are likely to reduce. Finally, reducing food waste is socially important when the rescued food is redirected to emergency food providers working to eliminate hunger in our communities.

Furthermore, we believe that through the results of this study it is proven that motivation to prevent food waste differs from a gender perspective. For a country that still upholds and adheres to patriarchal understanding, women are often faced with some household responsibilities, including financial management and managing dietary matters (food, food shopping, menus, nutrition and others). Therefore the results of the study strongly support this condition which shows that women have a higher motivation than men in trying to reduce and prevent food waste. This result is supporting study done by Koivupuro, et al (2012), which found the factors that influenced the amount of food wasted were the size of the household, the gender of the person mainly responsible of grocery shopping

\section{CONCLUSION AND RECOMMEN- DATION}

\section{Conclusion}

In conclusion, this research is an attempt to supplement the literature about food waste and to gain an understanding of what is a predictor of food waste organizing efforts. This current research has published several potential motivators (which are described in the concepts within instrument or questionnaire item) and used as targets in household food. The understanding and elaboration about this information in the future as might reveal several obstacles that may need to be overcome. In addition, this research also proves that gender is one of the distinguishing factors in measuring consumer motivation when making an effort to avoid food waste.

In this study it can be concluded that there are several main factors that underline consumers to monitor their food shopping behavior. The first reason is to save or save money is one of the motivations of consumers when trying to manage food waste. The second reason is that it is more directed at social values, namely to give examples to others. So it can be concluded in the motivation of food waste prevention there are two big clusters that are related to social and financial values. It is also considered from the examination that gender has proven to differentiate how consumers' motivation in food prevention, and women have stronger motivation compared to men, this is because women in Indonesia also generally act as managers who manage household finances.

We must try to change various views on some of the obstacles to minimizing household food waste, such as the belief that household food waste does not pose a serious environmental threat, it may be relatively easy to overcome through disseminating information on deadly food waste both environmental and financially. But from a business perspective, other obstacles, such as potentially conflicting desires to become 'good' providers, can prove more challenging to handle and may require more innovative approaches.

\section{Future Research Recommendation}

Food waste studies (and all of the issues within its topic, like food planning and management, food shopping behavior, food waste evaluation) should not be considered as too narrow. The ability to show how an apparently narrow topic relates to a larger theme increments the contributions, moving the research into a wider area of influence (Van Ittersum \& Wansink 2016). There is an opportunity to both expand the body of theory related to consumer food waste, which would help to explain and predict behavior, and to conduct studies aimed at fostering food waste prevention campaigns (Porpino, 2016). Further research into consumers and 
food waste can contribute to the sharpening of consumer behavior theories and the application of these theories to sustainable consumption and the interactions observed in consumer's food wastage (Shwom \& Lorenzen, 2012) so to make it more comprehensive, it is highly recommended to add other various predictors form that is not from individual point of view, but rather to external factors such as regulations and consideration of society assessment.

\section{REFERENCES}

Abeliotis, K., Lasaridi, K., \& Chroni, C. (2014). Attitudes and behaviour of Greek households regarding food waste prevention. Waste Management \& Research, 32(3), 237240.

Aktas, E., Sahin, H., Topaloglu, Z., Oledinma, A., Huda, A. K. S., Irani, Z., . \& Kamrava, M. (2018). A consumer behavioural approach to food waste. Journal of Enterprise Information Management, 31(5), 658-673

Aschemann-Witzel, J., De Hooge, I., Amani, P., Bech-Larsen, T., \& Oostindjer, M. (2015). Consumerrelated food waste: Causes and potential for action. Sustainability, 7(6), 6457-6477

Baumeister, R. F. (2002). Yielding to temptation: Self-control failure, impulsive purchasing, and consumer behavior. Journal of consumer Research, 28(4), 670676.
Bräutigam, K. R., Jörissen, J., \& Priefer, C. (2014). The extent of food waste generation across EU-27: Different calculation methods and the reliability of their results. Waste Management \& Research, 32(8), 683-694

Cohen, J.F.W., Richardson, S., Austin, S.B. (2013). School Lunch Waste among Middle School Students: Implications for Nutrients Consumed and Food Waste Costs, American Journal of Preventive Medicine, Feb; 44(2): 114-121.

Evans, D. (2012). Beyond the throwaway society: ordinary domestic practice and a sociological approach to household food waste. Sociology, 46(1), 41-56.

Ghani, W. A. W. A. K., Rusli, I. F., Biak, D. R. A., \& Idris, A. (2013). An application of the theory of planned behaviour to study the influencing factors of participation in source separation of food waste. Waste management, 33(5), 1276-1281.

Graham-Rowe, E., Jessop, D. C., \& Sparks, P. (2014). Identifying motivations and barriers to minimising household food waste. Resources, conservation and recycling, 84, 15-23.

Graham-Rowe, E., Jessop, D. C., \& Sparks, P. (2015). Predicting household food waste reduction using an extended theory of planned behaviour. Resources, Conservation and Recycling, 101, 194-202.

Klöckner, C. A. (2015). The psychology of pro-environmental communication: beyond standard information strategies. Springer. 
Koivupuro, H. K., Hartikainen, H., Silvennoinen, K., Katajajuuri, J. M., Heikintalo, N., Reinikainen, A., \& Jalkanen, L. (2012). Influence of socio-demographical, behavioural and attitudinal factors on the amount of avoidable food waste generated in Finnish households. International journal of consumer studies, 36(2), 183-191.

Kuo, C.F., Shih, Y. (2016). Gender differences in the effects of education and coercion on reducing buffet plate waste. Journal of Foodservice Business Research, 19(3), 223-235

Leal Filho, W., \& Kovaleva, M. (2015). Food waste and sustainable food waste management in the Baltic Sea Region. Hamburg, Germany: Springer.

Neff, R. A., Spiker, M. L., \& Truant, P. L. (2015). Wasted food: US consumers' reported awareness, attitudes, and behaviors. PloS one, 10(6), e0127881.

Parizeau, K., von Massow, M., \& Martin, R. (2015). Household-level dynamics of food waste production and related beliefs, attitudes, and behaviours in Guelph, Ontario. Waste management, 35, 207-217.

Porpino, G. (2016). Household food waste behavior: avenues for future research. Journal of the Association for Consumer Research, 1(1), 4151.

Quested, T. E., Marsh, E., Stunell, D., \& Parry, A. D. (2013). Spaghetti soup: The complex world of food waste behaviours. Resources, Conservation and Recycling, 79, 43-51
Shwom, R., \& Lorenzen, J. A. (2012). Changing household consumption to address climate change: social scientific insights and challenges. Wiley Interdisciplinary Reviews: Climate Change, 3(5), 379-395.

Silvennoinen, K., Katajajuuri, J., \& Hartikainen, H. (2014). Food waste volume and composition in Finnish households, British Food Journal, 116(6), 1058-1068

Stefan, V., van Herpen, E., Tudoran, A. A., \& Lähteenmäki, L. (2013). Avoiding food waste by Romanian consumers: The importance of planning and shopping routines. Food Quality and Preference, 28(1), 375-381.

Van Ittersum, K., \& Wansink, B. (2016). The behavioral science of eating: encouraging boundary research that has impact. Journal of the Association for Consumer Research, 1(1), 5-14

Visschers, V. H., Wickli, N., \& Siegrist, M. (2016). Sorting out food waste behaviour: A survey on the motivators and barriers of selfreported amounts of food waste in households. Journal of Environmental Psychology, 45, 66-78.

WRAP. Food behavior consumer research: Quantitative phase. 2

Zepeda, L., \& Li, J. (2006). Who buys local food?. Journal of food distribution research, 37(8562016-56238), 1-11. 